\title{
EFFECT OF THE INTROGRESSION OF ATLANTIC BROWN TROUT, SALMO TRUTTA, INTO ADRIATIC TROUT, SALMO FARIOIDES IN A STREAM AT THE DRAINAGE AREA OF THE ADRIATIC SEA BASIN OF MONTENEGRO
}

\author{
Dubravka ŠKRABA JURLINA*, Ana MARIĆ ${ }^{1}$, Jelena KARANOVIĆ ${ }^{1}$, Vera NIKOLIĆ ${ }^{1}$, \\ Miloš BRKUŠANIN ${ }^{1}$, Tamara KANJUH ${ }^{1}$, Danilo MRDAK ${ }^{2}$, and Predrag SIMONOVIĆ ${ }^{1,3}$ \\ ${ }^{1}$ University of Belgrade, Faculty of Biology, Belgrade, Serbia \\ ${ }^{2}$ University of Montenegro, Faculty of Sciences, Podgorica, Montenegro \\ ${ }^{3}$ University of Belgrade, Institute for Biological Research "Siniša Stanković”, Belgrade, Serbia
}

Škraba Jurlina D., Marić A., Karanović J., Nikolić V., Brkušanin M., Kanjuh T., Mrdak D., Simonović P. 2018. Effect of the introgression of Atlantic brown trout, Salmo trutta, into Adriatic trout, Salmo farioides in a stream at the drainage area of the Adriatic Sea basin of Montenegro. Acta Ichthyol. Piscat. 48 (4): $363-372$.

Background. The diversity of wild trout stocks in Montenegro is compromised by insufficiently controlled stocking. Adriatic and Mediterranean areas show a high degree of endemism of the salmonid species, with numerous native Salmo taxa described. The invasive effect of brown trout, Salmo trutta Linnaeus, 1758, of the Atlantic haplogroup on the endemic Adriatic trout, Salmo farioides Karaman, 1938, in the drainage area of the Adriatic Sea basin is lower compared to the effect inflicted by S. trutta has on Salmo labrax Pallas, 1814 of the Danubian haplogroup. The presently reported study was intended to describe the genetic structure of the population of Adriatic trout, Salmo farioides, from the Mrtvica River, a right tributary of the Morača River, Montenegro, in order to get an insight into the spread of non-native strains and their introgression into the native Adriatic trout gene pool.

Material and methods. Trout specimens sampled from the lower section of the Mrtvica River from 2004 to 2007 , and from its upper section in the spring of 2014, were analysed for their mtDNA haplotypes. Nuclear DNA markers (microsatellites, $\mathrm{LDH}-\mathrm{Cl} 1^{*}$ gene) were also included in genetic analyses since mtDNA is inherited only maternally. After statistical analyses, relations between individuals from the upper and lower Mrtvica River were reconstructed.

Results. Using both $\mathrm{LDH}-\mathrm{Cl}{ }^{*}$ and seven microsatellite loci with several alleles exclusive to $S$. trutta, an introgression was detected only in the upper reaches of the Mrtvica River, where only stream-dwelling trout form occurs. In the lower reaches no introgression was detected at all, as revealed by the absence of both the Atlantic mitochondrial haplotype and microsatellite alleles exclusive to $S$. trutta.

Conclusion. The allelic frequency at seven microsatellite loci of Salmo spp. from the two river sections revealed very different population structure, as a consequence of a low rate of gene flow between them. In addition to the physical barrier that prevents Salmo sp. from the lower Mrtvica River to migrate to the upper river section, it seems that the opportunity to mate with the large pool of conspecifics, including lake-dwelling $S$. farioides (i.e., Salmo cf. dentex), prevents Salmo trutta from surviving at the lower reach and spread to the rest of the Morača River and Lake Skadar systems.

Keywords: trout, Adriatic Sea basin, stream- and lake-dwelling, mtDNA, microsatellites

\section{INTRODUCTION}

The inconsistency of the taxonomy of trout (Salmo spp.) (see Kottelat 1997) resulted in the description of numerous nominal species (and subspecies). In order to resolve this taxonomic confusion, new techniques, using various molecular markers, have been extensively employed in the last two decades. The first comprehensive study of the genetic variation of the mtDNA control region (CR) sequence among geographically distant trout Salmo spp. populations (Bernatchez et al. 1992) revealed five major 
phylogenetic assemblages (Danubian, Atlantic, Adriatic, Mediterranean, and marmoratus). The most widely adopted recent categorization of mitochondrial haplogroups in Salmo spp. was provided by Bernatchez (2001) and Suárez et al. (2001) who distinguished six main evolutionary lineages of trout: the Danubian (DA), Atlantic (AT), Adriatic (AD), Mediterranean (ME), marmoratus (MA), and Duero (DU). In the Adriatic region, only MA, AD, and ME phylogenetic lineages are considered autochthonous (Giuffra et al. 1994, Apostolidis et al. 1997, Snoj et al. 2000). The use of mitochondrial DNA (mtDNA) markers (Berg and Ferris 1984, Gyllensten and Wilson 1987, Bernatchez 2001, Suárez et al. 2001, Snoj et al. 2002, 2010, Sušnik et al. 2004, Cortey et al. 2004, Bardakci et al. 2006, Turan et al. 2011, Simonović et al. 2015) and nuclear markers (Ferguson and Fleming 1983, Antunes et al. 2002, Hashemzadeh Sagherloo et al. 2012, Pustovrh et al. 2014, Araguas et al. 2017) revealed that the genus Salmo is genetically a highly structured taxon and therefore, effective conservation strategies need to be focused on the population level. Genetic screening of variation in brown trout, Salmo trutta Linnaeus, 1758, has been largely applied towards evaluating introgression of hatchery strains into wild populations (Hansen and Loeschcke 1994, Arias et al. 1995, Largiadèr and Scholl 1995).

The control region (CR) of mtDNA, nuclear lactate dehydrogenase (LDH) gene, and microsatellites have proved to be very good and widely applied molecular markers in resolving genetic and phylogenetic problems within the genus Salmo. Suitable nuclear genetic marker system used in the study on the population genetics and phylogeography of the Salmo spp. is $\mathrm{LDH}-\mathrm{Cl}$ * gene, whose polymorphism enables discrimination between particular phylogeographic lineages. The two most common alleles are $* 100$ (found throughout the taxon range), and $* 90$ (naturally restricted to the populations from north-western Europe) (Hamilton et al. 1989). Those alleles represent the AT haplogroup within the genus Salmo. The majority of hatchery stocks generated from Salmo sp. of the AT lineage in Europe show a very high frequency of the $* 90$ allele. For that reason, the $* 90$ allele is a convenient marker for the success of stocked fish and subsequent introgression, especially when hatchery fish are stocked into the Mediterranean or Black Sea drainages, where $* 90$ does not occur naturally and where native populations have a high frequency of the $* 100$ allele (McMeel et al. 2001). Microsatellites are also very useful for detecting gene flow and admixture between indigenous, relocated, or domesticated populations (Hansen 2002, Jug et al. 2005), apart from their use in the analysis of the population structure.

The goal of this study was to describe the population and genetic structure of Salmo farioides Karaman, 1938 from the Mrtvica River, Montenegro. Mrdak et al. (2006) reported the finding of the MN87p haplotype (renamed to Ad-M1 in Sušnik et al. 2007, GenBank accession number DQ381566) of $S$. farioides from the lower reaches of the river. However, there was no information on the population from the upper part of the river, which is, due to the high elevation gradient and several cascades, separated from the river's lower reaches. Therefore, the aim of our study was to describe the population and genetic structure of $S$. farioides population from the whole Mrtvica River, in order to determine if there are any differences between the two reaches of the stream (assigned the upper and lower Mrtvica River).

\section{MATERIALS AND METHODS}

The Mrtvica River is the right tributary of the upper Morača River, Montenegro, approximately $8 \mathrm{~km}$ long, with the headwaters in the high mountain slopes that descend to a broad mountain plateau. The Morača River is the biggest tributary of the Lake Skadar, contributing with $62 \%$ of the total water draining into the lake (Lasca et al. 1981).

In the lower Mrtvica River, the sampling was conducted by fishing with hooks and line, from 2004 to 2007, while samples from the upper Mrtvica River were obtained by electrofishing, in the spring of 2014 (Fig. 1). Tissue samples ( 4-mm ${ }^{2}$ anal fin clips), collected from 11 trout from the lower reaches and 12 individuals from the upper reaches, were stored in $96 \%$ ethanol. After sampling, the fish were released into the water, DNA was extracted using the High Salt Extraction technique (Miller et al. 1988). Amplification of the control region (CR) of mtDNA was carried out using the forward primers 28Riba (Snoj et al. 2000) and Trutta mt_F (5'-TGAATGAACCTGCCCTAGTAGC-3', designed by Miloš Brkušanin), and the reverse primer HN20 (Bernatchez and Danzmann 1993), following the protocol from Tošić et al. (2014). PCR products were purified and sequenced at Macrogen Europe. Sequencing reactions were performed in a DNA Engine Tetrad 2 Peltier Thermal Cycler (BIO-RAD) using the ABI BigDye Terminator v3.1 Cycle Sequencing Kit (Applied Biosystems), following the protocols supplied by the manufacturer by single-pass sequencing on each template using the forward (Trutta mt_F) primer. Obtained sequences were aligned with those from the GenBank using program Mega 7.0.21 (Larkin et al. 2007).

The partial LDH gene was amplified using Ldhxon3F and Ldhxon4R primers (McMeel et al. 2001) and polymorphisms of the amplified fragments were detected using SatI endonuclease for CR mtDNA and BseLI for LDH, under the conditions given in Marić et al. (2010).

Seven microsatellite loci (Table 1) were included in this analysis: Ssa85 (O'Reilly et al. 1996), Str73INRA (Estoup et al. 1993), SSsp2216 (Paterson et al. 2004), Ssa410Uos (Cairney et al. 2000), SsaD190, SsaD71 (King et al. 2005), and OMM1064 (Rexroad et al. 2002). They were combined in three duplex and one single reactions, with forward primer labelled with a fluorescent dye (FAM or NED) (Table 1). Fragment analysis was performed using GeneScan 500 LIZ Size Standard (Applied Biosystems, USA) on an ABI3130 Genetic Analyzer (Applied Biosystems, USA). The analysis was done using GeneMapper ID v3.2.1 (Applied Biosystems, USA). Microsatellite allele frequencies, observed and expected heterozygosity $(\mathrm{Ho}, \mathrm{He})$, and the number of alleles per locus were obtained using Genetix $4.05^{*}$ software (Tables 2 and 3). Allelic richness, 
pairwise values $F$ is and $F$ st, and test on Hardy-Weinberg equilibrium were performed in Arlequin 3.5.1.2 (Excoffier and Lischer 2010) and Fstat 2.9.3.2.* software packages (Tables 2-5). Difference in frequencies of alleles between the Salmo spp. in the upper and lower Mrtvica River was

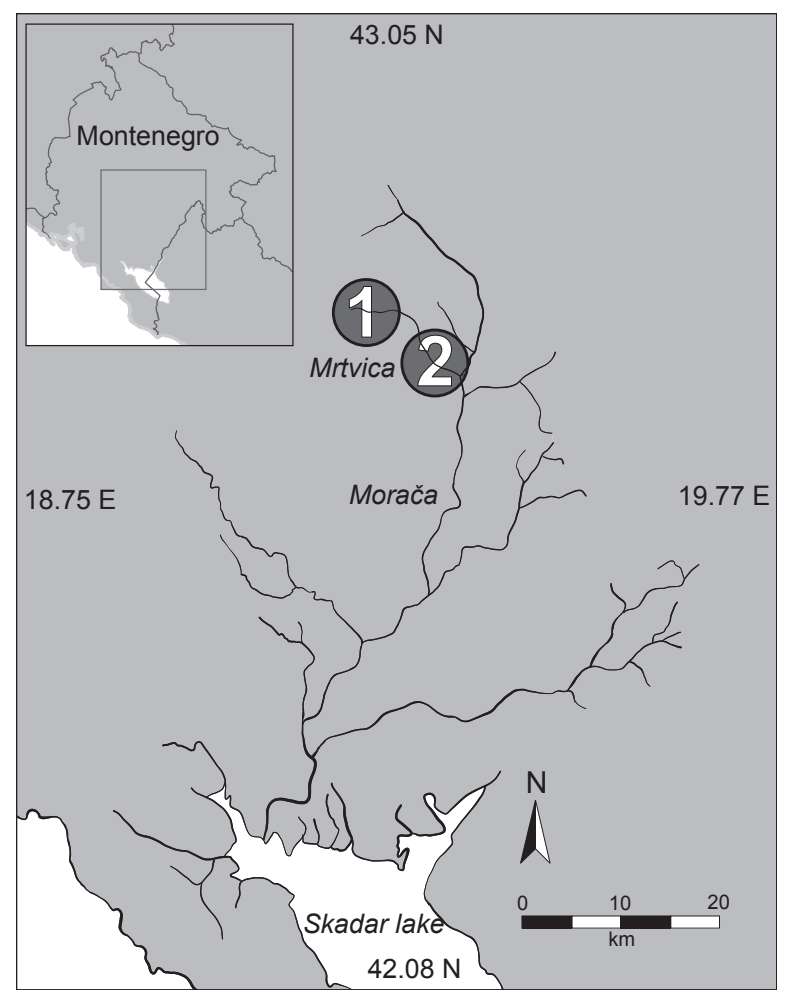

Fig. 1. Sampling sites at the Mrtvica River, Montenegro; $1=$ upper reach, 2 = lower reach examined by Structure 2.3.4 software (Falush et al. 2007), with the length of the burning period of $10^{4}$ and $10^{5}$ Markov chain Monte Carlo (MCMC) repeats for arrangements of clusters, using the Admixture Model, allele frequencies set as correlated, number of clusters $K=5$ and seven iterations. The best estimated $K$ by its $\Delta K$ value was assessed using the Structure Harvester-Taylor0! (Earl and vonHoldt 2012). Relations between individuals from the upper and lower Mrtvica River, inferred using allele frequencies of their microsatellite loci, were revealed by Neighbour-Joining clustering method, using the Shared Allele Distances (Chakraborty and Jin 1993). Calculation of Shared Allelic Distances was worked out in the Populations 1.2.31***

\section{RESULTS}

The final alignment of the $700 \mathrm{bp}$ long sequence of the CR mtDNA, obtained using the new Trutta_mt_F primer, indicated the presence of two main haplogroups of Salmo spp. in the Mrtvica River, namely AD (twenty individuals) and AT (three individuals). Fish sampled in the upper section belonged to both AD and AT lineages; Salmo farioides revealed one haplotype, ADcs11 (GenBank accession number AY836340, Cortey et al. 2004), while Salmo trutta (individuals $\mathrm{Mr} 1, \mathrm{Mr} 4$, and $\mathrm{Mr} 7$ ) revealed one haplotype, A17, from the AT lineage (GenBank accession number HQ848368, Kohout et al. 2012). All trout sampled in the lower section of the river belonged to the AD haplogroup; nine individuals had the ADcs11 haplotype, one individual had the Ad+Prz haplotype (GenBank accession number DQ318129, Marić et al. 2006), and one individual had the AD-M1 haplotype.

Restriction fragment length polymorphism (RFLP) of nuclear LDH gene was used to check for interbreeding

Table 1

Analyzed microsatellite loci, their structure, expected PCR products length, and primers used for their amplification with fluorescent label (FAM or NED)

\begin{tabular}{|c|c|c|c|c|c|c|}
\hline 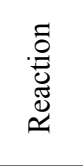 & Locus & Repeated motive & Colour & Primer sequence & Reference & $\begin{array}{c}\text { Expected } \\
\text { product } \\
\text { length } \\
\text { [bp] }\end{array}$ \\
\hline FDR & Str73INRA & $(\mathrm{GT}) \times$ TTATCT $(\mathrm{GT}) 3$ & FAM & $\begin{array}{l}\text { 5'-CCTGGAGATCCTCCAGCAGGA-3' } \\
\text { 5'-CTATTCTGCTTGTAACTAGACCTA-3' }\end{array}$ & $\begin{array}{l}\text { Estoup et al. } \\
1993\end{array}$ & $138-144$ \\
\hline FDR & Ssa410Uos & $(\mathrm{GACA}) \times$ & FAM & $\begin{array}{l}\text { 5'-GGAAAATAATCAATGCTGCTGGTT-3' } \\
\text { 5'-CTACAATCTGGACTATCTTCTTCA-3' }\end{array}$ & $\begin{array}{l}\text { Cairney et al. } \\
2000\end{array}$ & $173-310$ \\
\hline SDR & SsaD190 & $(\mathrm{TAGA}) \times$ & FAM & $\begin{array}{l}\text { 5'-GGCATTGGAGGTAAGGACAC-3' } \\
\text { 5'-CCAGACCACTGAACTTCTCATC-3' }\end{array}$ & $\begin{array}{l}\text { King et al. } \\
2005\end{array}$ & $115-157$ \\
\hline SDR & SsaD71 & $($ TAGA $) \times$ & FAM & $\begin{array}{l}\text { 5'-AACGTGAAACATAAATCGATGG-3' } \\
\text { 5'-TTAAGAATGGGTTGCCTATGAG-3' }\end{array}$ & $\begin{array}{l}\text { King et al. } \\
2005\end{array}$ & $183-239$ \\
\hline TDR & Ssa85 & $(\mathrm{GT}) 14$ & FAM & $\begin{array}{l}\text { 5'-AGGTGGGTCCTCCAAGCTAC-3' } \\
\text { 5'-ACCCGCTCCTCACTTAATC-3' }\end{array}$ & $\begin{array}{l}\text { O’Reilly et al. } \\
1996\end{array}$ & $101-113$ \\
\hline TDR & SSsp2216 & (GTTA) 25 & NED & $\begin{array}{l}\text { 5'-GGCCCAGACAGATAAACAAACACC-3' } \\
\text { 5'-GCCAACAGCAGCATCTACACCCAG-3' }\end{array}$ & $\begin{array}{l}\text { Paterson et al. } \\
2004\end{array}$ & $133-215$ \\
\hline FSR & OMM1064 & (GATA)19 & NED & $\begin{array}{l}\text { 5'AGAATGCTACTGGTGGCTGTATTGTA-3' } \\
\text { 5'-TCTGAAAGACAGGTGGATGGTTCC-3' }\end{array}$ & $\begin{array}{l}\text { Rexroad et al. } \\
2002\end{array}$ & $163-286$ \\
\hline
\end{tabular}

$\mathrm{FDR}=$ first duplex reaction, $\mathrm{SDR}=$ second duplex reaction, $\mathrm{TDR}=$ third duplex reaction, $\mathrm{FSR}=$ Fourth single reaction.

\footnotetext{
http://www.genetix.univmontp2.fr/genetix/intro.htm

** http://www2.unil.ch/popgen/softwares/fstat.htm.

*** http://bioinformatics.org/populations.
} 
between AD and AT haplogroups from the upper Mrtvica River. Two out of 12 individuals ( $\mathrm{Mr} 1$ and $\mathrm{Mr} 4)$ with the A17 haplotype were heterozygotes $\left(L D H-C^{*} 90 / 100\right)$, as well as two individuals (Mr8 and Mr9) with the ADcs11 haplotype inherited from mothers hybridized with males with the A17 haplotype. Remaining individuals were homozygotes $\left(L D H-C^{*} 100 / 100\right)$ and they belonged to either ADcs11 (Mr2, Mr3, Mr5, Mr6, Mr10, Mr11, and Mr12), or A17 (Mr7) haplotypes (Fig. 2).

As for the microsatellites in the Mrtvica River trout stock, several alleles exclusive to AD and AT lineages were detected (Table 6).

The mean ( \pm standard deviation) gene diversity of the Salmo spp. in the upper Mrtvica River was 0.503106 \pm 0.295779 , and in the lower section of the river, it was $0.620284 \pm 0.355738$. A deviation from the HardyWeinberg equilibrium was detected only for the locus SsaD71 in Salmo spp. from the upper Mrtvica River $\left(H_{\mathrm{o}}=0.16667, H_{\mathrm{e}}=0.72826, P<0.001\right)$ and for the locus Ssa410Uos from the lower Mrtvica River $\left(H_{\mathrm{o}}=0.81818\right.$, $\left.H_{\mathrm{e}}=0.94372, P<0.05\right)$. The mean $H_{\mathrm{o}}$ values calculated using all seven microsatellite loci for the upper and lower Mrtvica River were $0.50000 \pm 0.23570$ and $0.58442 \pm$ 25636, and mean $H_{\mathrm{e}}$ values were $0.50311 \pm 0.16790$ and $0.62028 \pm 0.25987$, respectively (Tables 2 and 3). Salmo farioides from the lower Mrtvica River revealed greater

Table 2

Test on Hardy-Weinberg equilibrium for Salmo sp. population from the upper reach of the Mrtvica River, Montenegro

\begin{tabular}{ccccc}
\hline Locus & $H_{\mathrm{o}}$ & $H_{\mathrm{e}}$ & $P$ & $\mathrm{SD}$ \\
\hline 1 & 0.58333 & 0.53986 & 0.59551 & 0.00111 \\
2 & 0.16667 & 0.72826 & 0.00000 & 0.00000 \\
3 & 0.41667 & 0.35870 & 1.00000 & 0.00000 \\
4 & 0.75000 & 0.63768 & 0.14874 & 0.00115 \\
5 & 0.41667 & 0.34420 & 1.00000 & 0.00000 \\
6 & 0.83333 & 0.61232 & 0.57182 & 0.00126 \\
7 & 0.33333 & 0.30072 & 1.00000 & 0.00000 \\
\hline
\end{tabular}

$H_{\mathrm{o}}=$ observed heterozygosity, $H_{\mathrm{e}}=$ expected heterozygosity, $\mathrm{SD}=$ standard deviation.

Test on Hardy-Weinberg equilibrium for Salmo sp. population from the lower reach of the Mrtvica River, Montenegro

\begin{tabular}{ccccc}
\hline Locus & $H_{\mathrm{o}}$ & $H_{\mathrm{e}}$ & $P$ & $\mathrm{SD}$ \\
\hline 1 & 0.45455 & 0.64502 & 0.05552 & 0.00076 \\
2 & 0.81818 & 0.93939 & 0.29345 & 0.00048 \\
3 & 0.81818 & 0.50649 & 0.06515 & 0.00069 \\
4 & 0.81818 & 0.94372 & 0.02523 & 0.00025 \\
5 & 0.18182 & 0.31169 & 0.27950 & 0.00140 \\
6 & 0.36364 & 0.32468 & 1.00000 & 0.00000 \\
7 & 0.63636 & 0.67100 & 0.75932 & 0.00134 \\
\hline
\end{tabular}

$H_{\mathrm{o}}=$ observed heterozygosity, $H_{\mathrm{e}}=$ expected heterozygosity, $\mathrm{SD}=$ standard deviation. allelic richness for SsaD71 and Ssa410Uos microsatellite loci (Table 5). A significant pairwise linkage disequilibrium between loci Str73INRA, Ssa85 and OMM1064 was detected in Salmo spp. from the upper Mrtvica River, whereas in the lower Mrtvica River it occurred between loci Ssa190 and SsaD71. AMOVA revealed that variation among populations $\left(V_{\mathrm{a}}=0.55380,22.06 \%\right.$ of total variation) was much lower than within populations $\left(V_{\mathrm{b}}=1.95661,77.97 \%\right)$, giving the Fixation Index value of $F_{\mathrm{ST}}=0.22060(P<0.001)$. Fstat calculated for all seven loci $F_{\text {IS }}=0.035$ and $F_{\text {IT }}=0.247$. For the entire river, low variation among population, $V_{\mathrm{a}}=-0.00681$, and $F_{\mathrm{ST}}=$ -0.04321 values $(P=1.00000)$, were detected only for the locus Ssa85; all other loci revealed significant genetic differentiation among Salmo spp. with $F_{\mathrm{ST}}$ values varying from 0.10152 to 0.40536 . The negative values of $F_{\text {IS }}$ for the majority of microsatellite loci in Salmo spp. from the upper Mrtvica River suggest the strong inbreeding between them, in contrast to positive $F_{\text {IS }}$ values in the $S$. farioides from the lower Mrtvica River (Table 5).

Salmo spp. from the upper and lower reaches of the Mrtvica River were grouped in distinct clusters ( $K$ = 2), with the $\Delta K=39.321459$ (Fig. 3), with the mean distances, i.e., expected heterozygosities of 0.6977 and 0.5002 between individuals in each of them, respectively. The memberships of each pre-defined population in each
Table 4

Allelic richness per locus in Salmo spp. from the Mrtvica River, Montenegro

\begin{tabular}{lcrc}
\hline $\begin{array}{c}\text { Microsatellite } \\
\text { locus }\end{array}$ & $\begin{array}{c}\text { Upper } \\
\text { Mrtvica } \\
\text { River }\end{array}$ & $\begin{array}{c}\text { Lower } \\
\text { Mrtvica } \\
\text { River }\end{array}$ & $\begin{array}{c}\text { Upper and } \\
\text { lower } \\
\text { Mrtvica River }\end{array}$ \\
\hline SsaD190 & 4.830 & 4.000 & 5.594 \\
SsaD71 & 6.822 & 13.000 & 11.339 \\
Str73INRA & 2.917 & 2.000 & 3.413 \\
Ssa410Uos & 4.830 & 12.000 & 9.887 \\
Ssa85 & 2.000 & 2.000 & 1.999 \\
SSsp2216 & 4.830 & 3.000 & 5.020 \\
OMM1064 & 2.917 & 3.000 & 4.338 \\
\hline
\end{tabular}

Table 5

$F_{\text {IS }}$ values for each microsatellite locus and per all loci in Salmo spp. from the Mrtvica River, Montenegro

\begin{tabular}{lcc}
\hline $\begin{array}{c}\text { Microsatellite } \\
\text { locus }\end{array}$ & $\begin{array}{c}\text { Upper } \\
\text { Mrtvica River }\end{array}$ & $\begin{array}{c}\text { Lower } \\
\text { Mrtvica River }\end{array}$ \\
\hline SsaD190 & -0.085 & 0.306 \\
SsaD71 & 0.779 & 0.135 \\
Str73INRA & -0.170 & -0.667 \\
Ssa410Uos & -0.186 & 0.139 \\
Ssa85 & -0.222 & 0.429 \\
SSsp2216 & -0.384 & -0.127 \\
OMM1064 & -0.114 & 0.054 \\
\hline All loci & 0.006 & 0.054
\end{tabular}


of the two clusters $K$ were $87.5 \%$ and $94.9 \%$, respectively, and uRM7) and heterozygous for LDH-C (uRM1, uRM4, and the Net nucleotide distance between them was 0.1087. uRM8, and uRM9) gene were close, indicating gene flow Mean $F_{\mathrm{ST}}$ values of 0.0051 for Salmo spp. at the upper and hybridization between them in this river sector. reach and 0.2971 for those in the lower reach characterized their genetic differentiation as very low and high, respectively. Neighbour-Joining clustering of individuals

\section{DISCUSSION}

The occurrence of three AD haplotypes in the native by Shared Allelic Distances between them confirmed that Salmo farioides at both reaches of the Mrtvica River Salmo spp. from the two Mrtvica River reaches belong suggests their dynamic and complex evolutionary history. to the two distinct clusters (Fig. 4), i.e., populations, with Given the isolation of Salmo spp. at the upper Mrtvica the very limited gene flow $N_{\mathrm{m}}=0.442$ between them. River from those at the lower section of the river, the Relation between Salmo spp. individuals in the population ADcs11 haplotype seems ancestral to AD-M1 haplotype at the upper Mrtvica River of AT linage (uRM1, uRM4, that occurs only in the lower reaches, which is consistent

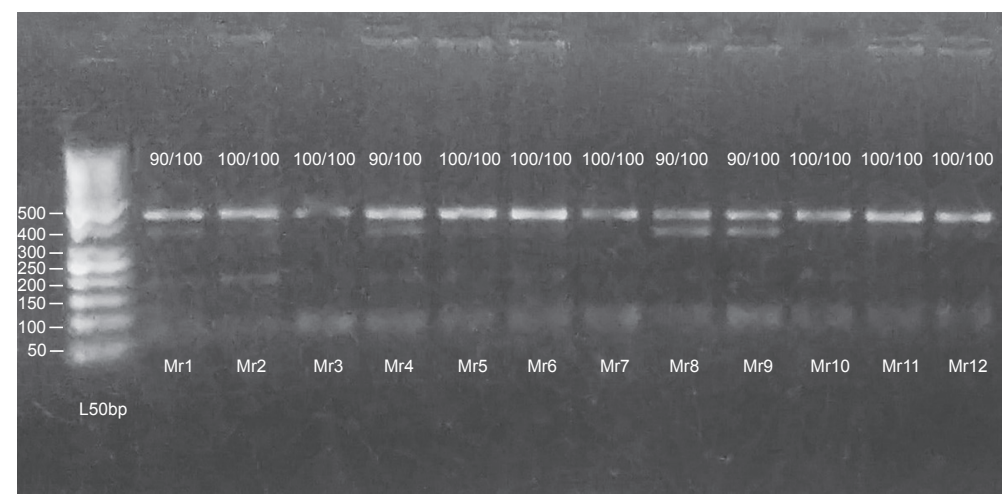

Fig. 2. RFLP reaction of the partial $L D H^{*} C 1$ gene in Salmo sp. from the upper reach of the Mrtvica River, Montenegro; fragment sizes are shown alongside a $50 \mathrm{bp}$ ladder (on the left)

Table 6

Alleles at seven microsatellite loci of 23 trout samples from the Mrtvica River, Montenegro

\begin{tabular}{|c|c|c|c|c|c|c|c|c|c|c|c|c|c|c|c|c|}
\hline \multirow{2}{*}{$\begin{array}{l}\text { Sample } \\
\text { Mr01 }\end{array}$} & \multirow{2}{*}{$\frac{\mathrm{K}}{1}$} & \multicolumn{2}{|c|}{ SsaD190 } & \multicolumn{2}{|c|}{ SsaD71 } & \multicolumn{2}{|c|}{ Str73INRA } & \multicolumn{2}{|c|}{ Ssa410Uos } & \multicolumn{2}{|c|}{ Ssa85 } & \multicolumn{2}{|c|}{ SSsp2216 } & \multicolumn{2}{|c|}{ OMM1064 } & \multirow{2}{*}{$\begin{array}{c}\text { mtDNA } \\
\text { A17 }\end{array}$} \\
\hline & & 116 & 144 & 444 & 452 & 140 & 140 & 200 & 284 & 06 & 106 & 156 & 168 & 200 & 200 & \\
\hline $\mathrm{Mr02}$ & 1 & 144 & 164 & 200 & 200 & 140 & 142 & 228 & 284 & 106 & 110 & 156 & 168 & 200 & 200 & ADcs 11 \\
\hline Mr03 & 1 & 144 & 164 & 200 & 200 & 140 & & 236 & 280 & 106 & 110 & 168 & & 200 & 256 & \\
\hline Mr04 & 1 & 152 & 164 & 200 & 200 & 140 & 144 & 228 & 284 & 106 & 106 & & & 200 & 200 & A17 \\
\hline Mr05 & 1 & 164 & 16 & 168 & 16 & 14 & & & & 106 & 110 & & & & & \\
\hline Mr06 & 1 & 164 & 164 & 452 & 45 & 14 & 14 & 4 & 284 & 106 & 110 & 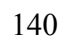 & 168 & 200 & 256 & ADcs 11 \\
\hline Mr07 & 1 & 152 & 164 & 192 & 19 & 14 & & 4 & 284 & 106 & 106 & & & & 200 & A17 \\
\hline Mr08 & 1 & 164 & 16 & 196 & 196 & 14 & & 228 & 284 & 106 & 106 & & 168 & 200 & 200 & ADcs 11 \\
\hline Mr09 & 1 & 136 & 16 & 200 & 200 & 14 & & 228 & 280 & 106 & 106 & 168 & 184 & 200 & 216 & ADcs 11 \\
\hline Mr10 & 1 & 144 & 16 & 200 & 200 & 14 & & 228 & 284 & 106 & 110 & & & & & ADcs11 \\
\hline Mr11 & 1 & 164 & 16 & 200 & 20 & 14 & & 228 & 28 & 106 & 106 & & 16 & 200 & 200 & ADcs 11 \\
\hline Mr12 & 1 & 164 & 164 & 448 & 45 & 14 & & 228 & 28 & & 106 & & & & & ADcs 11 \\
\hline Mr76 & 2 & 136 & 16 & 196 & 50 & 13 & & 236 & 30 & 110 & 110 & 1 & 168 & 200 & 208 & ADcs11 \\
\hline & 2 & 168 & 168 & 240 & 4 & & & & & & & & & & & \\
\hline Mr79 & 2 & 168 & 168 & 244 & 452 & 13 & & 276 & 292 & 106 & 106 & & 172 & 204 & 208 & ADcs 11 \\
\hline & 2 & 164 & 16 & 256 & 256 & 13 & & 276 & & 100 & & & & & & \\
\hline Mr82 & 2 & 168 & 168 & 196 & 196 & 138 & & 256 & 256 & 106 & 106 & & 168 & 204 & 208 & ADcs 11 \\
\hline Mr83 & 2 & 164 & 164 & 452 & 464 & 138 & & 264 & 284 & 106 & 110 & & & 200 & 208 & \\
\hline Mr84 & 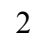 & 168 & 168 & 244 & 496 & 138 & 140 & 284 & 288 & 106 & 106 & 168 & 168 & 208 & 208 & ADcs 11 \\
\hline Mr85 & 2 & 164 & 164 & 308 & 312 & 138 & 140 & 260 & 280 & 106 & 106 & 168 & 168 & 204 & 204 & $\mathrm{Ad}+\operatorname{Prz}$ \\
\hline Mr86 & 2 & 136 & 168 & 144 & 244 & 138 & 14 & 260 & 280 & 106 & 106 & 164 & 168 & 200 & 204 & ADcs 11 \\
\hline Mr87 & 2 & 136 & 168 & 196 & 452 & 138 & 140 & 248 & 252 & 106 & 106 & 168 & 172 & 208 & 208 & AD-M1 \\
\hline Mr88 & 2 & 136 & 140 & 444 & 504 & 138 & 138 & 252 & 252 & 106 & 106 & 168 & 168 & 200 & 204 & ADcs 11 \\
\hline
\end{tabular}

$\mathrm{K}$ = population, 1 = upper reach, 2 = lower reach; $\mathrm{mtDNA}=\mathrm{CR}$ haplotype; alleles exclusive for $\mathrm{AD}$ lineage are italicized and those exclusive for AT lineage are bolded. 
with the findings of Mrdak et al. (2006). According to Sušnik et al. (2007), Ad+Prz is a sister clade of the lineage containing Adcs11 and AD-M1 haplotypes, both being within the AD haplogroup. The occurrence of the AD+Prz haplotype only in the lower Mrtvica River implies that it introgressed there after the isolation of the upper Mrtvica River when the single transversion at the new polymorphic nucleotide site 256 in the ADcs 11 has already occurred to derive the AD-M1 haplotype.

The finding of Salmo sp. of the allochthonous AT haplogroup in the Mrtvica River was unexpected, particularly in individuals having the A17 haplotype. Their occurrence in the highly elevated streams of the Adriatic Sea basin in Montenegro is most likely the consequence of stocking. Numerous native Salmo taxa have been described within the Adriatic and Mediterranean areas, which is characterized by a high degree of endemism of the salmonid species (Behnke 1973), as well as high phenotypic diversity among trout populations (Bernatchez 2001). Apostolidis et al. (2011) concluded that it is not clear whether these taxa are phenotypic variants or distinct species. In addition to the marble trout, Salmo marmoratus Cuvier, 1829, and the softmouth trout, Salmo zetensis (Hadzisce, 1960), who are clearly distinct, three other Salmo species were reported for the Morača River system: Adriatic trout Salmo farioides, Salmo montenigrinus Karaman, 1933, and "strun" Salmo dentex (Heckel, 1851) (see Drecun 1962, Ivanović 1973, Šorić 1990, Maric 1995). Based on mtDNA control region and exon 13 of transferrin gene, as well as information obtained through field investigations and observations, Mrdak et al. (2006) and Snoj et al. (2010) concluded that in Montenegro, Salmo cf. dentex is an ecomorph of Adriatic trout $S$. farioides from Lake Skadar, which migrate upstream to the spawning grounds in the upper Morača River. According to Marić and Milošević (2011), only one trout species, the Adriatic trout ( $S$. farioides), occurs in the Morača River system.

The presently reported A17 haplotype constitutes the first record of this haplotype in the Balkans and the
Adriatic Sea basin and it suggests a single stocking event of the Mrtvica River with Salmo trutta, as no other allochthonous haplotypes were recorded there. Recently reported occurrence of the Atcs1 haplotype in brown trout in many streams attractive for angling throughout the western Balkans (Snoj 2004, Marić et al. 2006, 2012, Jadan et al. 2007, Simonović et al. 2015, Mrdak unpublished*), as well as the hatchery origin of the brown trout reported by Marić et al. (2010), raise a question about the period of domestication and stocking of S. trutta of the otherwise

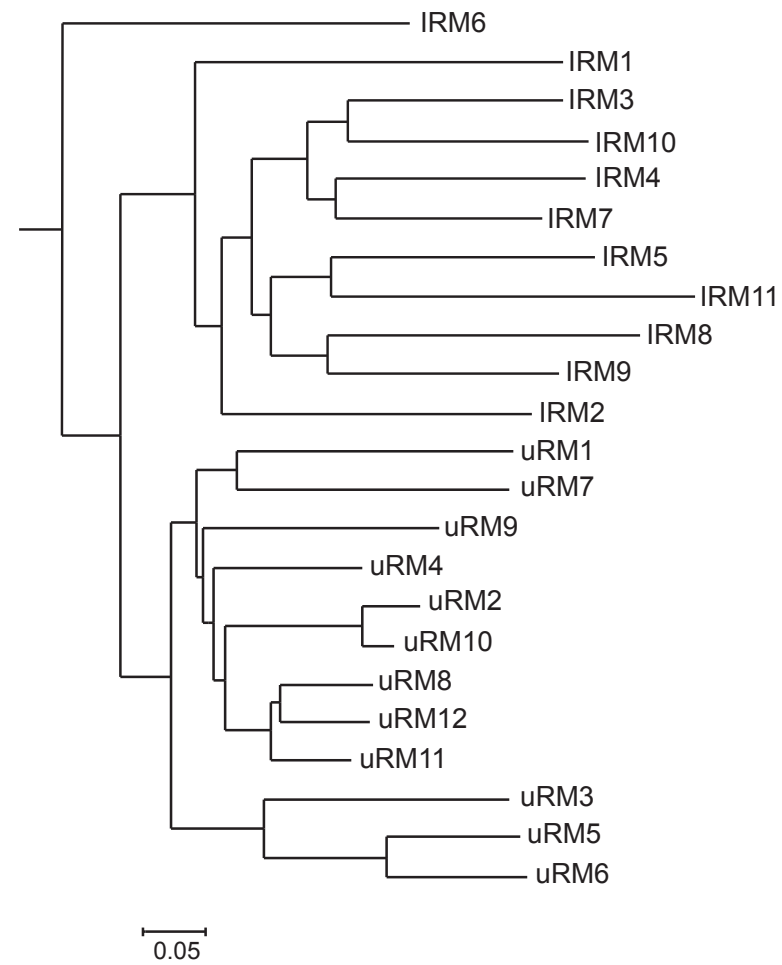

Fig. 4. Relations between Salmo spp. individuals from the upper (u) and lower (1) Mrtvica River (RM), Montenegro as revealed by Neighbour-Joining clustering method and Shared Allelic Distances between them, calculated from the allelic structure on seven microsatellite loci

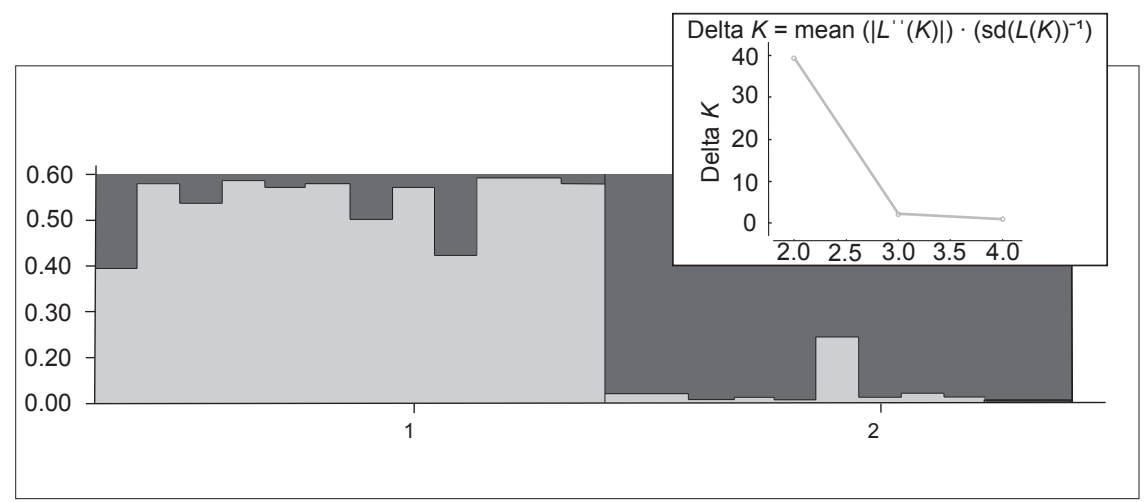

Fig. 3. Visualization of the structure of genotypes in Salmo spp. from the upper (1) and lower (2) Mrtvica River, Montenegro, as revealed by allelic structure on the seven microsatellite loci (larger picture) and the best number of clusters $K$ estimated by $\Delta K$ value (smaller picture)

"Mrdak D. 2011. Pastrmke (Salmo L., 1758) rijeka Crne Gore - diverzitet, taksonomski status i filogenetski odnosi. [Trout (Salmo L., 1758) of streams in MontenegroDiversity, taxonomic status, and phylogenetic relations.] Doctoral Dissertation, University of Belgrade, Belgrade, Serbia. [In Serbo-Croatian.] 
uncommon A17 haplotype, that far from their reported native range (Kohout et al. 2012).

The results of the presently reported study impose the question as to why trout with the A17 mtDNA marker could not migrate downstream since they are not recorded in the lowermost section of the Mrtvica River and in the Morača River system (Sušnik et al. 2007). We hypothesize that there are three possible scenarios that are not necessarily exclusive:

- There is a stronger fishing pressure in that, easily accessible reach of the stream, so that trout are fished out quickly

- Trout with the A17 haplotype disappear due to stronger selection pressure at the spawning sites they share with the migratory form of Adriatic trout Salmo farioides (formerly denoted Salmo cf. dentex) (Mrdak et al. 2006), so they fail to survive or reproduce there

- The number of Salmo trutta with the A17 haplotype in the upper section is too low to allow successful gene flow $\left(N_{\mathrm{m}}=0.442\right)$ into the gene pool of $S$. farioides in the lower Mrtvica River

All three scenarios are supported by the lack of microsatellite alleles exclusive for Salmo sp. of the A17 haplotype in S. farioides at the lower Mrtvica River and by high genetic differentiation between Salmo sp. from the two river sections (Fig. 4).

Negative $F_{\text {IS }}$ values for almost all microsatellite loci in samples from the upper Mrtvica River indicate inbreeding rates higher than expected and, therefore, low population number of trout in that river section. Such a situation favours hybridization because a lower number of Salmo sp. of the AT lineage can have a stronger genetic impact on the original Salmo farioides gene pool. This was supported by relations reconstructed from microsatellite loci (Fig. 4), as well as by the occurrence of deviation from the HardyWeinberg equilibrium ( $H_{\mathrm{o}}$ and $H_{\mathrm{e}}$ values), implying a lack of panmixia in this river part. The population in the lower Mrtvica River was far more diverse than that in the upstream section, as indicated by $F_{\mathrm{ST}}$ and $F_{\text {IS }}$ values, and allelic richness.

Generally, many native Salmo spp. populations are threatened by anthropogenic activities, such as environmental degradation, harvesting, and stocking, that may swamp indigenous gene pools and lower the fitness of local populations (Hansen 2002). Introduction of domesticated, hatchery-reared Salmo sp. (commonly of AT haplogroup, hence Salmo trutta) was detected throughout the western Balkans (Simonović et al. 2017), where its invasive effect of introgression into the native gene pool of recipient, native trout stocks of the DA lineage, was revealed (Marić et al. 2012), and the risk of their invasiveness had already been assessed as high in Serbia (Simonović et al. 2015). Fortunately, the situation concerning the impact of $S$. trutta on $S$. farioides in the Mrtvica River seems somewhat different.

The introgression of Salmo trutta into the gene pool of the Salmo farioides was detected only in the upper Mrtvica River, where the two stream-dwelling Salmo spp. were sympatric. The upper Mrtvica River is a headwater only few meters wide, extremely limited in resources. In the past, older and larger individuals of the stream-dwelling $S$. farioides from the upper Mrtvica River probably had migrated downstream, which has maintained the integrity of population in the whole stream. However, the extreme reduction in their number in the upper Mrtvica River, that has occurred most likely due to poaching, caused a decline in the number of migrants. The stocking of non-native $S$. trutta in the upper Mrtvica River could have led to population structure changes and further differentiation from the population in the lower Mrtvica River. In that way, the genetic structure of the native $S$. farioides population in the fragile, improperly managed mountain stream could have been rapidly changed in a short-time period.

The lack of introgression, i.e., successful establishment of Salmo trutta of the AT haplogroup in the lower Mrtvica River (despite their introgression into the gene pool of the native Salmo farioides at the upper Mrtvica River), could be a consequence of difference in the population structure, i.e., the existence of two life-history forms there. In addition to the resident, stream-dwelling $S$. farioides in the lower Mrtvica River that are free to move to the large Morača River and to meet many conspecifics at their common spawning grounds, that river section is also visited by $S$. cf. dentex, the lake form of $S$. farioides, who migrate during the spawning season far upstream the Morača River from the Lake Skadar, to meet stream-dwelling conspecifics. Mrdak (2011) sampled there two, and in the Morača River additional 11 Salmo cf. dentex, who had similar allele structure at microsatellite loci like stream-dwelling $S$. farioides, suggesting high interbreeding between the stream- and lake-dwelling forms. This is supported by occurrence of the Hardy-Weinberg equilibrium in the six out of seven microsatellite loci of $S$. farioides from the lower Mrtvica River, which implies panmixia. It is a fortunate outcome for the status of original diversity that $S$. farioides in the lower Mrtvica River and in the Morača River system so far still can cope with the alien Salmo trutta introduction.

\section{ACKNOWLEDGEMENTS}

Financial support for the presently reported study was granted by the Ministry of Education, Science and Technological Development of the Republic of Serbia (Grants \#173025 and \#173016).

\section{REFERENCES}

Antunes A., Templeton A.R., Guyomard R., Alexandrino P. 2002. The role of nuclear genes in intraspecific evolutionary inference: Genealogy of the transferrin gene in the brown trout. Molecular Biology and Evolution 19 (8): 1272-1287. DOI: 10.1093/ oxfordjournals.molbev.a004188

Apostolidis A.P., Stoumboudi M.T., Kalogianni E., Cote G., Bernatchez L. 2011. Genetic divergence among native trout Salmo trutta populations from southern Balkans based on mitochondrial DNA and 
microsatellite variation. Journal of Fish Biology 79 (7): 1950-1960. DOI: 10.1111/j.1095-8649.2011.03136.x

Apostolidis A.P., Triantaphyllidis C., Kouvatsi A., Economidis P.S. 1997. Mitochondrial DNA sequence variation and phylogeography among Salmo trutta L. (Greek brown trout) populations. Molecular Ecology 6 (6): 531-542. DOI: 10.1046/j.1365-294X.1997.d01176.x

Araguas R.M., Vera M., Aparicio E. Sanz N., Fernández-Cebrián R., Marchante C., GarcíaMarín J.L. 2017. Current status of the brown trout (Salmo trutta) populations within eastern Pyrenees genetic refuges. Ecology of Freshwater Fish 26 (1): 120-132. DOI: 10.1111/eff.12260

Arias J., Sánchez L., Martínez P. 1995. Low stocking incidence in brown trout populations from northwestern Spain monitored by $L D H-5 *$ diagnostic marker. Journal of Fish Biology 47 (Suppl. A): 170176. DOI: 10.1111/j.1095-8649.1995.tb06053.x

Bardakci F., Degerli N., Ozdemir O., Basibuyuk H.H. 2006. Phylogeography of the Turkish brown trout Salmo trutta L.: Mitochondrial DNA PCR-RFLP variation. Journal of Fish Biology 68 (A): 36-55. DOI: 10.1111/j.0022-1112.2006.00948.x

Behnke R. 1973. Systematic problems of the Salmonidae fishes endemic to the Adriatic-Mediterranean province and the potential for developing new information from new techniques. Pp. 19-21. I Congress of the European Ichthyological Society, 21-29 September 1973, Sarajevo, Bosnia and Herzegovina, Book of Abstracts.

Berg W.J., Ferris S.D. 1984. Restriction endonuclease analysis of salmonid mitochondrial DNA. Canadian Journal of Fisheries and Aquatic Sciences 41 (7): 1041-1047. DOI: 10.1139/f84-121

Bernatchez L. 2001. The evolutionary history of brown trout (Salmo trutta L.) inferred from phylogeographic, nested clade and mismatch analyses of mitochondrial DNA variation. Evolution 55 (2): 351-379. DOI: 10.1111/j.0014-3820.2001.tb01300.x

Bernatchez L., Danzmann R.G. 1993. Congruence in control-region sequence and restriction-site variation in mitochondrial DNA of brook charr (Salvelinus fontinalis Mitchill). Molecular Biology and Evolution 10 (5): 1002-1014. DOI: 10.1093/oxfordjournals. molbev.a040062

Bernatchez L., Guyomard R., Bonhomme F. 1992. DNA sequence variation of the mitochondrial control region among geographically and morphologically remote European brown trout Salmo trutta populations. Molecular Ecology 1 (3): 161-173. DOI: 10.1111/j.1365-294X.1992.tb00172.x

Cairney M., Taggart J.B., Høyheim B. 2000. Characterization of microsatellite and minisatellite loci in Atlantic salmon (Salmo salar L.) and crossspecies amplification in other salmonids. Molecular Ecology 9 (12): 2175-2178. DOI: 10.1046/j.1365294X.2000.105312.x
Chakraborty R., Jin L. 1993. A unified approach to study hypervariable polymorphisms: Statistical considerations of determining relatedness and population distances. DOI: 10.1007/978-3-0348-8583$6 \_14$ Pp. 153-175. In: Pena S.D.J., Chakraborty R., Epplen J.T., Jeffreys A.J. (eds.) DNA Fingerprinting: State of the science. Birkhauser Verlag, Basel, Switzerland. DOI: 10.1007/978-3-0348-8583-6

Cortey M., Pla C., García-Marín J.-L. 2004. Historical biogeography of Mediterranean trout. Molecular Phylogenetics and Evolution 33 (3): 831-844. DOI: 10.1016/j.ympev.2004.08.012

Drecun Đ. 1962. Rasprostranjenje i popis slatkovodnih riba Crne Gore. [Spread and register of freshwater fishes in Montenegro.] Hydrobiologa Montenegrina 2 (1): 1-8. [In Serbo-Croatian.]

Earl D.A., vonHoldt B.M. 2012. STRUCTURE HARVESTER: A website and program for visualizing STRUCTURE output and implementing the Evanno method. Conservation Genetics Resources 4 (2): 359-361. DOI: 10.1007/s12686-011-9548-7

Estoup A., Presa P., Krieg F., Vaiman D., Guyomard R. 1993. (CT)n and (GT)n microsatellite: A new class of genetic markers for Salmo trutta L. (brown trout). Heredity 71 (5): 488-496. DOI: 10.1038/hdy.1993.167

Excoffier L., Lischer H.E. 2010. Arlequin suite ver 3.5: A new series of programs to perform population genetics analyses under Linux and Windows. Molecular ecology resources 10 (3): 564-567. DOI: 10.1111/j.1755-0998.2010.02847.x

Falush D., Stephens M., Pritchard J.K. 2007. Inference of population structure using multilocus genotype data: Dominant markers and null alleles. Molecular Ecology Notes 7 (4): 574-578. DOI: 10.1111/j.14718286.2007.01758.x

Ferguson A., Fleming C.C. 1983. Evolutionary and taxonomic significance of protein variation in the brown trout (Salmo trutta L.) and other salmonid fishes. Pp. 84-99. In: Oxford G.S., Rollinson D. (eds.) Protein polymorphism: Adaptive and taxonomic significance. Academic Press, London, UK.

Giuffra E., Bernatchez L., Guyomard R. 1994. Mitochondrial control region and protein coding genes sequence variation among phenotypic forms of brown trout Salmo trutta from northern Italy. Molecular Ecology 3 (2): 161-171. DOI: 10.1111/j.1365294X.1994.tb00117.x

Gyllensten U., Wilson A.C. 1987. [12] Mitochondrial DNA of salmonids: Inter- and Intraspecific Variability Detected with Restriction Enzymes. Pp. 301-317. In: Ryman N., Utter F. (eds.) Population genetics and fisheries management. University of Washington Press, Seattle WA, USA.

Hamilton K.E., Fergusson A., Taggart J.B., Tómasson T., Walker A., Fahy E. 1989. Post-glacial colonization of brown trout, Salmo trutta L.: Ldh-5 as a phylogenetic marker locus. Journal of Fish Biology 35 (5): 651-664. DOI: $10.1111 /$ j.1095-8649.1989.tb03017.x 
Hansen M.M. 2002. Estimating the long-term effects of stocking domesticated trout into wild brown trout (Salmo trutta) populations: An approach using microsatellite DNA analysis of historical and contemporary samples. Molecular Ecology 11 (6): 1003-1015. DOI: 10.1046/j.1365-294X.2002.01495.X

Hansen M.M., Loeschcke V. 1994. Effects of releasing hatchery-reared brown trout to wild trout populations. Pp. 273-289. In: Loeschcke V., Tomiuk J., Jain S.K. (eds.) Conservation Genetics. Birkhauser Verlag, Basel, Switzerland.

Hashemzadeh Segherloo I., Farahmand H., Abdoli A., Bernatchez L., Primmer C.R., Swatdipong A., Karami M., Khalili B. 2012. Phylogenetic status of brown trout Salmo trutta populations in five rivers from the southern Caspian Sea and two inland lake basins, Iran: A morphogenetic approach. Journal of Fish Biology 81 (5): 1479-1500. DOI: 10.1111/j.10958649.2012.03428.x

Ivanović B. 1973. Ichthyofauna of Skadar Lake. Institut za biološka i medicinska istraživanja, Titograd, Yugoslavia.

Jadan M., Čož-Rakovac R., Topić Popović N., Strunjak Perović I. 2007. Presence of unexpected phylogenetic lineages of brown trout Salmo trutta L. in Gacka River, Croatia. Aquaculture Research 38 (15): 1682-1685. DOI: $10.1111 / \mathrm{j} .1365-2109.2007 .01832 . x$

Jin L., Chakraborty R. 1993. Estimation of genetic distance and coefficient of gene diversity from singleprobe multilocus DNA fingerprinting data. Molecular Biology and Evolution 11 (1): 120-127. DOI: 10.1093/ oxfordjournals.molbev.a040086

Jug T., Berrebi P., Snoj A. 2005. Distribution of nonnative trout in Slovenia and their introgression with native trout populations as observed through microsatellite DNA analysis. Biological Conservation 123 (3): 381-388. DOI: 10.1016/j.biocon.2004.11.022

King T.L., Eackles M.S., Letcher B.H. 2005. Microsatellite DNA markers for the study of Atlantic salmon (Salmo salar) kinship, population structure, and mixed-fishery analyses. Molecular Ecology Notes 5 (1): 130-132. DOI: 10.1111/j.14718286.2005.00860.x

Kohout J., Jašková I., Papoušek I., Šedivá A., Šlechta V. 2012. Effects of stocking on the genetic structure of brown trout, Salmo trutta, in Central Europe inferred from mitochondrial and nuclear DNA markers. Fisheries Management and Ecology 19 (3): 252-263. DOI: $10.1111 / \mathrm{j} .1365-2400.2011 .00828 . \mathrm{x}$

Kottelat M. 1997. European freshwater fishes. An heuristic checklist of the freshwater fishes of Europe (exclusive of former USSR), with an introduction for non-systematists on nomenclature and conservation. Biologia, Bratislava, Section Zoology 52 (Suppl. 5): 1-271.

Largiadèr C.R., Scholl A. 1995. Effects of stocking on the genetic diversity of brown trout populations of the Adriatic and Danubian drainages in Switzerland.
Journal of Fish Biology 47 (Suppl. A): 209-225. DOI: 10.1111/j.1095-8649.1995.tb06057.x

Larkin M.A., Blackshields G., Brown N.P., Chenna R., McGettigan P.A., McWilliam H., Valentin F., Wallace I.M., Wilm A., Lopez R., Thompson J.D., Gibson T.J., Higgins D.G. 2007. Clustal W and Clustal X version 2.0. Bioinformatics 23 (21): 2947 2948. DOI: 10.1093/bioinformatics/btm404

Lasca N.P., Radulović V., Ristič R.J., Cherkauer D.S. 1981. Geology, hydrology, climate and bathymetry of Lake Skadar. Pp. 17-38. In: Karaman G.S., Beeton A.M. (eds.). The biota and limnology of Lake Skadar. Univerzitet Veljko Vlahovic, Titograd, Yugoslavia.

Maric D. 1995. Endemic fish species of Montenegro. Biological Conservation 72 (2): 187-194. DOI: 10.1016/0006-3207(94)00081-Z

Marić D., Milošević D. 2011. Katalog slatkovodnih riba (Osteichthyes) Crne Gore. [Catalogue of the Freshwater Fishes (Osteichthyes) of Montenegro.] Crnogorska akademija nauka i umjetnosti. Katalozi 5, Knjiga 4. Podgorica, Montenegro. [In Serbian.]

Marić S, Nikolić V., Tošić A., Simonović P. 2012. Record of the brown trout Salmo trutta L., 1758 in the main riverbed of the Serbian part of the Danube River. Journal of Applied Ichthyology 28 (1): 135-137. DOI: 10.1111/j.1439-0426.2011.01881.x

Marić S., Simonović P., Razpet A. 2010. Genetic characterization of broodstock brown trout from Bled fish-farm, Slovenia. Periodicum Biologorum 112 (2): 145-148.

Marić S., Sušnik S., Simonović P., Snoj A. 2006. Phylogeographic study of brown trout from Serbia, based on mitochondrial DNA control region analysis. Genetics Selection Evolution 38 (4): 411-430. DOI: 10.1051/gse:2006012

McMeel O.M., Hoey E.M., Ferguson A. 2001. Partial nucleotide sequences, and routine typing by polymerase chain reaction-restriction fragment length polymorphism, of the brown trout (Salmo trutta) lactate dehydrogenase, $\mathrm{LDH}-\mathrm{Cl} * 90$ and $* 100$ alleles. Molecular Ecology 10 (1): 29-34. DOI: 10.1046/j.1365-294X.2001.01166.x

Miller S.A., Dykes D.D., Polesky H.F.R.N. 1988. A simple salting out procedure for extracting DNA from human nucleated cells. Nucleic Acids Research 16 (3): 1215. DOI: $10.1093 / \mathrm{nar} / 16.3 .1215$

Mrdak D., Simonović P., Sušnik S., Snoj A. 2006. The existence of "strun" - Salmo dentex (Heckel, 1851) as distinct species from Salmo trutta fario (Linnaeus, 1758), in Adriatic rivers of Montenegro. Pp. 137142. In: II International Symposium of Ecologists of Montenegro, 20-25 June 2006, Kotor, Montenegro, Proceedings of the Symposium.

O'Reilly P.T., Hamilton L.C., McConnell S.K., Wright J.M. 1996. Rapid analysis of genetic variation in Atlantic salmon (Salmo salar) by PCR multiplexing of dinucleotide and tetranucleotide microsatellites. Canadian Journal of Fisheries and Aquatic Sciences 53 (10): 2292-2298. DOI: 10.1139/f96-192 
Paterson S., Piertney S.B., Knox D., Gilbey J., Verspoor E. 2004. Characterization and PCR multiplexing of novel highly variable tetranucleotide Atlantic salmon (Salmo salar L.) microsatellites. Molecular Ecology Notes 4 (2): 160-162. DOI: 10.1111/j.1471-8286.2004.00598.x

Pustovrh G., Snoj A., Sušnik Bajec S. 2014. Molecular phylogeny of Salmo of the western Balkans, based upon multiple nuclear loci. Genetics Selection Evolution 46: e7. DOI: $10.1186 / 1297-9686-46-7$

Rexroad C.E.III, Coleman R.L., Hershberger W.K., Killefer J. 2002. Rapid communication: Thirty-eight polymorphic microsatellite markers for mapping in rainbow trout. Journal of Animal Science 80 (2): 541542. DOI: $10.2527 / 2002.802541 x$

Simonović P., Tošić A., Škraba Jurlina D., Nikolić V., Piria M., Tomljanović T., Šprem N., Mrdak D., Milošević D., Bećiraj A., Dekić R., Povž M. 2017. Diversity of brown trout Salmo cf. trutta in the River Danube basin of western Balkans as assessed from the structure of their mitochondrial control region haplotypes. Journal of Ichthyology 57 (4): 603-616. DOI: $10.1134 / \mathrm{S} 0032945217040154$

Simonović P., Vidović Z., Tošić A., Škraba D., Čanak-Atlagić J., Nikolić V. 2015. Risks to stocks of native trout of the genus Salmo (Actinopterygii: Salmoniformes: Salmonidae) of Serbia and management for their recovery. Acta Ichthyologica et Piscatoria 45 (2): 161-173. DOI: 10.3750/AIP2015.45.2.06

Snoj A. 2004. Filogeografska struktura postrvi (Salmo trutta L.) v Sloveniji. [Philogeographic structure of trout (Salmo trutta L.) in Slovenia.] Ribič 2004 (10): 239-243. [In Slovenian.]

Snoj A., Jug T., Melkič E., Sušnik S., Pohar J., Dovč P., Jesenšek D., Budihna N. 2000. Mitochondrial and microsatellite DNA analysis of marble trout in Slovenia. Quaderni ETP 29: 5-11.

Snoj A., Glamuzina B., Razpet A., Zablocki J., Bogut I., Lerceteau-Köhler E., Pojskić N., Sušnik S. 2010. Resolving taxonomic uncertainties using molecular systematics: Salmo dentex and the Balkan trout community. Hydrobiologia 651 (1): 199-212. DOI: 10.1007/s10750-010-0297-5
Snoj A., Marčeta B., Sušnik S., Melkič E., Meglič V., Dovč P. 2002. The taxonomic status of the 'sea trout' from the north Adriatic Sea, as revealed by mitochondrial and nuclear DNA analysis. Journal of Biogeography 29 (9): 1179-1185. DOI: 10.1046/j.1365-2699.2002.00735.x

Suárez J., Bautista J.M., Almodóvar A., Machordom A. 2001. Evolution of mitochondrial control region in Palaeartic brown trout (Salmo trutta) populations: The biogeographical role of the Iberian Peninsula. Heredity 87 (2): 198-206. DOI: 10.1046/j.13652540.2001.00905.x

Sušnik S., Schöffman J., Snoj A. 2004. Phylogenetic position of Salmo (Platysalmo) platycephalus Behnke 1968 from south-central Turkey, evidenced by genetic data. Journal of Fish Biology 64 (4): 947-960. DOI: 10.1111/j.1095-8649.2004.0363.x

Sušnik S., Snoj A., Wilson I.F., Mrdak D., Weiss S. 2007. Historical demography of brown trout (Salmo trutta) in the Adriatic drainage including the putative $S$. letnica endemic to Lake Ohrid. Molecular Phylogenetics and Evolution 44 (1): 63-76. DOI: 10.1016/j.ympev.2006.08.021

Šrić V. 1990. Salmonids in the Ohrid-Drim-Skadar system. Acta Societatis Zoologicae Bohemoslovacaei 54 (4): 305-319.

Tošić A., Škraba D., Nikolić V., Mrdak D., Simonović P. 2014. New mitochondrial DNA haplotype of brown trout Salmo trutta L. from Crni Timok drainage area in Serbia. Turkish Journal of Fisheries and Aquatic Sciences 14 (1): 37-42. DOI: 10.4194/1303-2712v14_1_05

Turan D., Kottelat M., Bektaş Y. 2011. Salmo tigridis, a new species of trout from the Tigris River, Turkey (Teleostei: Salmonidae). Zootaxa 2993: 23-33.

Received: 4 June 2018 Accepted: 8 October 2018 Published electronically: 31 December 2018 